\title{
Oceanography
}

CITATION

Pugh, G., and D. Garrison. 2013. Quarterdeck: Particularly timely research at coastal Long Term Ecological Research sites. Oceanography 26(3):5, http://dx.doi.org/10.5670/oceanog.2013.67.

DOI

http://dx.doi.org/10.5670/oceanog.2013.67

COPYRIGHT

This article has been published in Oceanography, Volume 26, Number 3, a quarterly journal of The Oceanography Society. Copyright 2013 by The Oceanography Society. All rights reserved.

USAGE

Permission is granted to copy this article for use in teaching and research. Republication, systematic reproduction, or collective redistribution of any portion of this article by photocopy machine, reposting, or other means is permitted only with the approval of The Oceanography Society. Send all correspondence to: info@tos.org or The Oceanography Society, PO Box 1931, Rockville, MD 20849-1931, USA. 


\section{Particularly Timely Research at \\ Coastal Long Term Ecological Research Sites} OCEANOGRAPHY SOCIETY

Rockville, MD 20849-1931 USA

t: (1) 301-251-7708; f: (1) 301-251-7709

www.tos.org

The Oceanography Society was founded in 1988 to disseminate knowledge of oceanography and its application through research and education, to promote communication among oceanographers, and to provide a constituency for consensus-building across all the disciplines of the field.

OFFICERS

Mark Abbott, President Susan Lozier, President-Elect Mike Roman, Past-President Susan Cook, Secretary

Susan Banahan, Treasurer

\section{COUNCILLORS}

$\begin{array}{cc}\text { Amy Burgess } & \text { Blanche Meeson } \\ \text { Scott Glenn } & \text { Mary Scranton } \\ \text { Steven Lohrenz } & \text { Janet Sprintall } \\ \text { Gail Kineke } & \text { Deborah Steinberg }\end{array}$

EXECUTIVE DIRECTOR Jennifer Ramarui

SPONSORS

Lockheed Martin Sippican Inc. www.sippican.com

Ober | Kaler www.ober.com

Satlantic

www.satlantic.com

Sea-Bird Electronics Inc. www.seabird.com

Teledyne RD Instruments www.rdinstruments.com

WET Labs www.wetlabs.com
HOW WILL CHANGING ENVIRONMENTAL DRIVERS, such as a warming ocean and sea level rise, affect diverse coastal ecosystems over time? Can ecosystems perturbed by infrequent but major disruptions, such as hurricanes or oil spills, return to their pre-disturbance state? How will ocean acidification affect ecosystem functioning and biological processes in coastal systems? How do human activities interact with climate and environmental drivers over time? The National Science Foundation (NSF)-funded Long Term Ecological Research (LTER) coastal sites are well positioned to contribute the scientific knowledge needed for informed decision making in tackling these questions and the challenges the answers may bring. Many of the coastal LTER science objectives address goals of the NSF-wide Science, Engineering, and Education for Sustainability (SEES) effort, providing an opportunity for the LTERs to increase the scope of their activities and to contribute to the growing climate, environment, and sustainability portfolio at NSF.

It is critical to understand the complex dynamics of coastal ecosystem processes in order to meet the challenge of a sustainable world. Through analysis of experimental and observational data collected across broad spatial and temporal scales, coastal LTER researchers are gaining deeper insights into long-term effects that climate variability and change have on ecosystem processes and drivers.

Examples of current research include determining the effects of ocean acidification on community structure and habitat shifts in response to sea level rise and warming temperatures. Research discoveries involve a place-based system-level understanding of coastal ecosystems as well as cross-site comparisons among the different coastal environments.

In this special issue of Oceanography, researchers from the coastal LTER sites present highlights of new oceanographic technologies, from sensors to autonomous gliders; hydrodynamic modeling, from estuaries to submarine canyons; nutrient cycling in kelp forests, coral reefs, and salt marshes; and ecological interactions that include all types of organisms, from primary producers such as phytoplankton to top predators such as alligators. The contributions provide an in-depth view of the exciting, cutting-edge, fundamental ongoing research at these multidisciplinary research sites.

\footnotetext{
- Gayle Pugh and David Garrison, Biological Oceanography Program,
} National Science Foundation 